\title{
PREY CACHING BY NON- BREEDING NORTHERN HAWK OWLS IN ALBERTA
}

DOUGLAS M. COLLISTER, 3426 Lane Cr. S.W., Calgary, AB. T3E 5X2

Caching prey for later consumption has been reported for a number of wild owl species, although most accounts are of birds breeding or likely to be breeding: Short-eared Owl during May in Idaho ${ }^{9}$; breeding Northern Hawk Owls in Alaska ${ }^{8}$; non-breeding and breeding Northern Hawk Owls in Minnesota and throughout Manitoba'; a Northern Hawk Owl during the breeding season in Quebec ${ }^{6}$; Boreal Owls during the breeding season $^{5}$; and an Eastern Screech Owl

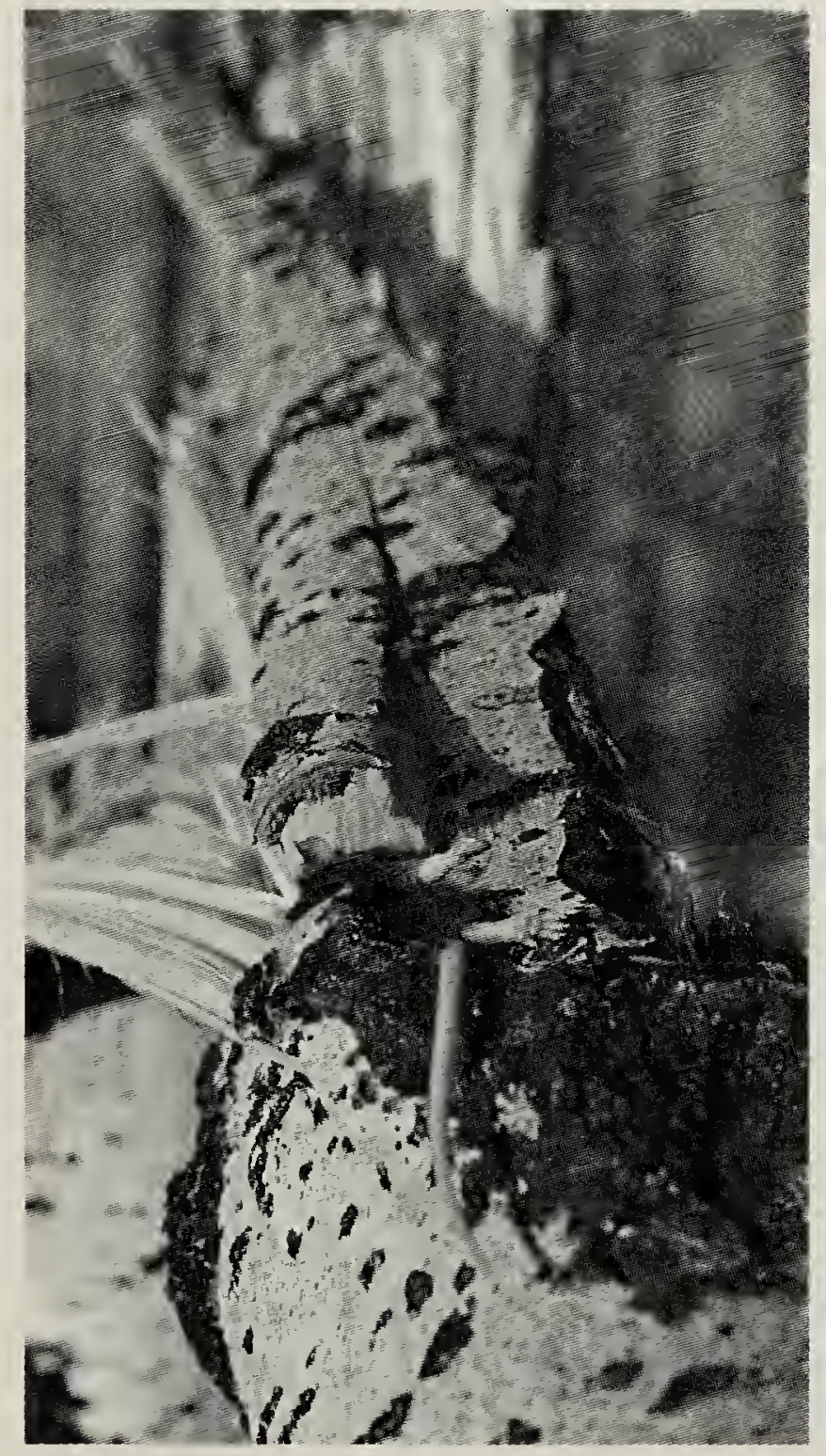

Cached Northern Hawk

Owl prey

Doug Collister during April in Ontario. ${ }^{7}$ Collins $^{2}$ reviewed caching by captive owls: prebreeding Northern Hawk Owls; breeding Great Horned Owls; and non-breeding Barn Owls.

Reports of caching by wild owls outside the breeding season are rare. The following documentation of caching by wild non-breeding Northern Hawk Owls during the winter in Alberta provides additional information on this behaviour.

On 26 January 1990 a Northern Hawk Owl was found perched, northwest of Calgary (51 $39^{\circ} \mathrm{N}, 114^{\circ} 34^{\prime} \mathrm{W}$ ), on top of a tree in a small grove of aspens next to a stubble field. For over an hour I tried to entice the bird to a free-ranging dark-coloured laboratory mouse in the stubble but elicited little response and did not effect a capture. As a last resort I moved into the aspen grove and immediately the owl came in and actually managed to steal the mouse and elude capture. I set up again and offered another mouse. The owl appeared to become agitated and cached the first mouse behind a piece of bark on a windfallen poplar. It then came in to the second mouse and was captured. Upon release no additional live mice were offered and the owl showed no interest in a frozen mouse carcass dragged with thread. On several previous occasions hawk owls have taken dead mice offered to them in this way by the author. Similarly, Duncan and Duncan ${ }^{3}$ found that only rarely did hawk owls not take small rodent carcasses when offered. 
On 8 January 1994 a Northern Hawk Owl was found perched, southwest of Calgary $\left(50^{\circ} 50^{\prime} \mathrm{N}\right.$, $114^{\circ} 29^{\prime} \mathrm{W}$ ), in an open aspen grove some $300 \mathrm{~m}$ distant on a southfacing hillside. It was lured in after several minutes to a free-ranging dark-coloured laboratory mouse and was netted for banding. After release the bird perched on a power pole overhead. Upon being offered a mouse on a fencepost the owl swooped down and took the prey item back to the power pole where the mouse was beheaded. The owl allowed the head to drop to the ground. When a second mouse was offered on the fencepost the owl flew to a nearby spruce tree within which it stashed the carcass of the first mouse. It then returned to the power pole and immediately swooped down to take the second mouse. This second mouse was taken to another spruce tree approximately $150 \mathrm{~m}$ distant and stashed. The owl then returned to the power pole and glowered expectantly at the "magic" fencepost. No additional live mice were provided and the owl did not respond to a frozen mouse carcass dragged with thread or an artificial lure.

Caching of prey is thought to be an adaptive advantage for any species dependent on a food source that fluctuates. $^{2}$ The availability of small rodents, that many owls depend on, is known to fluctuate yearly, seasonally, daily, and due to weather. Caching by non-breeding Northern Hawk Owls could be an adaptation to deal with daily fluctuations in prey abundance and the periodic occurrence of adverse weather. The Northern Hawk Owl is a resident of the northern boreal forest and is subject to extreme weather conditions yearround. Although thawing frozen cached prey is an energy drain on an owl, it may still be advantageous to store prey, especially during extreme cold. ${ }^{1}$ Northern owls, like the Northern Hawk Owl, may exhibit more highly developed caching behaviour due to the capacity of prey to be preserved for long periods in the cold northern climate.

Acknowledgements I thank J. Podlubny and D. Wicklum for field assistance. P. \& J. Duncan, A.J. Erskine, R.W. Nero and two anonymous reviewers provided helpful comments on an earlier draft of this note.

1. BONDRUP-NIELSEN, S. 1977. Thawing of frozen prey by boreal and saw-whet owls. Can. J. Zool. 55:595601.

2. COLLINS, C.T. 1976. Food-caching behaviour in owls. Raptor Research 10:74-76.

3. DUNCAN, P.A. and J.R. DUNCAN. 1995. Northern Hawk Owl (Surnia ulula). In The birds of North America, No. XXX (A. Poole and F. Gill, Eds.). Philadelphia: The Academy of Natural Sciences; Washington, D.C.: The American Ornithologists' Union. (in prep.)

4. EHRICH, P.R., D.S. DOBKIN and D. WHEYE. 1988. The birder's handbook. Simon \& Schuster Inc., New York. $785 \mathrm{pp}$.

5. KORPIMÄKI, E. 1987. Prey caching of breeding Tengmalm's Owls $\mathrm{Ae}$ golius funereus as a buffer against temporary food shortage. Ibis 129:499-510.

6. MCNAIR, D.B. 1994. Caching by an irruptive hawk-owl. Blue Jay 52:216217.

7. PHELAN, F.J.S. 1977. Food caching in the Screech Owl. Condor 79:127.

8. RITCHIE, R.J. 1980. Food caching behaviour of nesting wild Hawk Owls. Raptor Research 14:59-60.

9. YOUNG, L.S., CRENSHAW, J.G., and L.L. CRENSHAW. 1988. Food caching by a Short-eared Owl. The Murrelet 69:39. 